\title{
Synchronization Protein-Energy Index of Various Forages for Dairy Livestock: an In Vitro Study
}

\author{
Afduha Nurus Syamsi* and Hermawan Setyo Widodo \\ Animal Science Faculty, Jenderal Soedirman University, Purwokerto, Indonesia \\ *Correspondence author email: afduha.nurus.syamsi@unsoed.ac.id
}

\begin{abstract}
The present study inventoried the protein-energy synchronization (PES) index of various types of grass. The study was conducted using in vitro techniques with material 5 types of grass (elephant, king, dwarf elephant, guinea, and setaria) and rumen fluid of the Friesian Holstein (FH). The PES index is calculated based on the average degradation of g protein and $\mathrm{Kg}$ organic matter (OM) per hour at the time of observation of 2nd, 4th, 6th, 8th, 12th, 24th, 48th, and 72nd hours. The hourly degradation rates were analyzed by linear regression to obtain the average hourly degradation rate. The results were included in the PES index calculation formula and discussed descriptively. This study found that all five grass had almost uniform nutritional value. Regression analysis results show a different equation, but with a high coefficient of determination (>90\%) on all types of grass. The PES index obtained in elephant, king, dwarf elephant, guinea, and setaria grass are $0.72,0.66,0.69,0.58$, and 0.68 . The study concluded that elephant grass has a PES index at a high level, while king, dwarf elephant, guinea, and setaria grass at medium level for compiling dairy rations.
\end{abstract}

Keywords: synchronization protein-energi index ,forages, dairy, in vitro

Abstrak. Tujuan penelitian adalah untuk menginventarisir indeks sinkronisasi protein-energi (SPE) berbagai jenis rumput. Penelitian dilaksanakan menggunakan teknik in vitro dengan materi 5 jenis rumput (gajah, raja, odot, benggala, dan setaria) dan cairan rumen Sapi Friesian Holstein (FH). Indeks SPE dihitung berdasarkan rataan degradasi g protein dan $\mathrm{Kg}$ bahan organic (BO) per jam pada waktu pengamatan jam ke 2, 4, 6, 8, 12, 24, 48, dan 72. Degradasi pada tiap jam dianalisis dengan regresi linier untuk mendapatkan rataan degradasi per jam. Hasilnya dimasukan dalam rumus perhitungan indeks SPE dan dibahas secara deskriptif. Hasil penelitian menunjukkan bahwa kelima jenis rumput memiliki nilai nutrisi yang hampir seragam. Hasil analisis regresi menunjukkan persamaan yang berbeda, namun dengan koefisien determinasi yang tinggi (>90\%) pada semua jenis rumput. Indeks sinkronisasi yang didapat pada rumput gajah, raja, odot, benggala, dan setaria secara berurut yaitu $0.72,0.66,0.69,0.58$, dan 0.68 . Penelitian mendapatkan kesimpulan bahwa rumput gajah memiliki indeks sinkronisasi protein-energi pada level high, sedangkan rumput raja, odot, benggala, dan setaria pada level medium untuk menyusun ransum ternak perah.

Kata kunci: indeks sinkronisasi protein-energi, rumput, ternak perah, in vitro

\section{Introduction}

Forage is one of the important feed ingredients in raising dairy cattle, taking up 60\% $60 \%$ of the total ration for livestock. Forages that are commonly used by dairy farmers are from the grass group, such as elephant grass (Pennisetum purpureum), king grass (Pennisetum purpupoides), and Dwarf elephant grass (Pennisetum purpureum cv. Mott.). The advantages of grass as forage for dairy fodder are the palatability, nutritional value and good digestibility, and considerable production capacity in each planting period. The use of grass for dairy rations has long been adopted and maintained by farmers. However, many farmers are lack of knowledge on the principles of good ration preparation for livestock productivity.

The preparation of dairy rations should not only be directed at choosing the type and nutritional value of feed ingredients, but must also be based on improving the performance of rumen microorganisms. Optimizing the growth of rumen microorganisms is a strategic step in maximizing the utilization of feed for production (Syamsi et al., 2019). The growth of rumen microorganisms is influenced by the availability of nutrients in the right amount, 
composition and time. Nitrogen $(\mathrm{N})$ compounds and energy are required in the largest quantities and must be available simultaneously (synchronously). Animal ration must produce a balanced kinetic degradation of organic matter (OM) and protein. The kinematic balance of degradation of the two nutrients will supply synchronous ammonia and energy for rumen microbial protein synthesis (MPS). Syamsi et al. (2017) explained that the simultaneous availability of ammonia and energy in the rumen can be achieved through the ration based on protein-energy synchronization (PES) index.

Ginting (2005) states that the PES index data for local feed ingredients has not been inventoried despite its important role in the preparation of dairy rations. Inventory of PES index of feed ingredients (including grass groups) can be done through a study of the degradability of protein and organic material through in vivo techniques, but this method is limited by the need for fistulas and high cost. Silva et al. (2013), Syamsi et al. (2017), and Waldi et al. (2017) states that the PES index of feed ingredients can be measured in vitro. This study aimed to inventory the PES index of various types of grass as a basic effort to develop the PES index-based ration in dairy farming.

\section{Materials and Methods \\ Experimental Design}

Experimental research was carried out at the Laboratory of Nutrition and Animal Feed Science, Faculty of Animal Science, Jenderal Soedirman University for 3 months. The study was divided into 2 stages, the first stage was a proximate analysis of several types of grass. The materials included elephant grass (Pennisetum purpureum), king grass (Pennisetum purpupoides), dwarf elephant grass (Pennisetum purpureum cv. Mott), guinea grass (Panicum maximum), and setaria grass (Setaria sphacelata), each with a defoliation of $40-45$ days. The variables measured at this stage were dry matter (DM), organic matter (OM), ash, crude protein (CP), extract ether (EE), crude fiber (CF), nitrogen free extract (NFE), and total digestible nutrient (TDN).

The second step was measuring protein and $\mathrm{OM}$ in vitro degradation of each grass. The material was the rumen fluid of Friesian Holstein (FH) taken immediately after the cattle were slaughtered. The measured variables were protein degradation, OM degradation, and protein-energy synchronization (PES) index.

\section{Variable Analysis \\ Proximate Analysis of Grass}

Proximate analysis was performed by the AOAC method (2005) to determine the nutrient content of each grass. The DM levels were obtained by curing $2 \mathrm{~g}$ of the sample at $105^{\circ} \mathrm{C}$ for 8 hours or until the sample weight was stable. To measure the OM levels, $2 \mathrm{~g}$ of the sample was planted at $600^{\circ} \mathrm{C}$ for 12 hours. The extract ether of feed ingredients was produced by extracting $2 \mathrm{~g}$ of sample in soxhlet with ether solvent. One gram of sample was washed in different chemical solutions, such as $\mathrm{H} 2 \mathrm{SO} 4$, $\mathrm{NaOH}$, acetone, and aquadest to obtain the crude fiber content. Furthermore, the protein content was measured by distilling $0.1 \mathrm{~g}$ of sample, then the distillation results were titrated with $\mathrm{HCl}$ solution. The NFE levels were determined by following formulation, NFE = $100 \%$ - content (CP+EE+CF+ash). TDN levels were calculated based on (Hartadi et al., 1990) with the formula, TDN $=(70.60+0.259 \mathrm{CP}+$ $1.01 \mathrm{EE})-(0.76 \mathrm{CF}+0.0991 \mathrm{NFE})$. All grass were oven-dried at $60^{\circ} \mathrm{C}$ for 3 days.

\section{Measuring Grass Protein-Energy Synchronization (PES) Index}

The PES index was measured based on Silva et al. (2013) and Syamsi et al. (2017) through the measurement of protein and $\mathrm{OM}$ in vitro degradation of feed ingredients. In vitro digestion was performed using a $250 \mathrm{ml}$ 
Erlenmeyer filled with $4 \mathrm{~g}$ of grass sample, 32 $\mathrm{ml}$ of rumen fluid and $48 \mathrm{ml}$ of McDougall's solution. The Erlenmeyer was submersed in a shaker water bath at 390C, fed with $\mathrm{CO} 2$ for 30 seconds, and covered with a ventilated rubber. The time intervals to measure the degradation of each grass follows Orskov and McDonald (1979) were 2nd, 4th, 6th, 8th, 12th, 24th, 48th, and 72 nd hours. The degradation of protein and $\mathrm{OM}$ at each time was calculated based on the equation made by Tilley and Terry (1963) as follows:

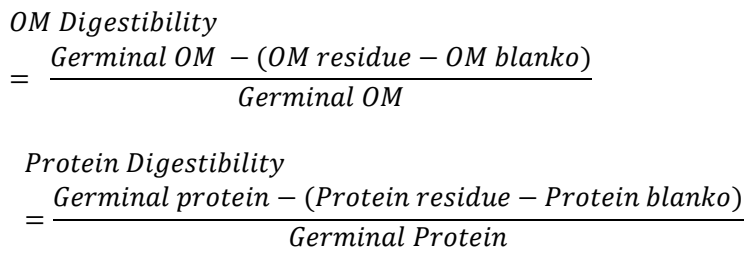

Protein and OM degradation rates at each subsequent time interval were analyzed in regression to obtain the degradation rate of gram $\mathrm{N}$ and kilograms OM per hour then used to calculate the PES index of each grass. The calculation formula is as follows:

$$
\text { PES index }=\frac{20-\sum_{1-24}^{n} \frac{\sqrt{\left(20-\frac{N}{O M} \text { ourly }\right)^{2}}}{24}}{20}
$$

Note: $\mathrm{n}$ : observation time, $\mathrm{N} / \mathrm{OM}$ hourly: rate of protein degradation compared to rate of degradation of organic matter every hour (Hermon et al., 2008).

\section{Data analysis}

The proximate analysis results were explained descriptively, and the results of measurements of protein and OM degradation were analyzed by regression. The results of protein and OM regression will be included in the PES index formula and the results will be discussed descriptively.

\section{Results and Discussion}

Grass belongs to class 2 of food ingredients class code, namely fresh forage which includes pasture forage, range plants, and forages fed green. The characteristic of fresh forage is the high water content (Utomo, 2012). Similarly, this study (Table 1) found that the dry matter (DM) of all types of grass ranges between 13.22 and $22.99 \%$, so grass is $>75 \%$ water. Purbajanti et al. (2007) stated that the type of forage influenced DM production. Additionally, the king's grass had the highest levels of DM among other forages. Table 1 shows that the DM of setaria and dwarf elephant grass was comparably lower than others because these plants had short stems. Additionally, the proportion of leaves compared to the stems was higher than other forages.

The proximate analysis results in general to five types of forage (Table 1) did not show a striking difference (OM, Ash, CP, EE, CF, NFE, and TDN). Weiss et al. (2008) explained that the quality of nutrients in forages is influenced by many factors, such as season, fertilization, type,

Table 1. Proximate analysis of various types of grass

\begin{tabular}{lcccccccc}
\hline Type of Forages & $\begin{array}{c}\text { DM } \\
(\%)\end{array}$ & $\begin{array}{c}\text { OM } \\
(\%)\end{array}$ & $\begin{array}{c}\text { Ash } \\
(\%)\end{array}$ & $\begin{array}{c}\text { CP } \\
(\%)\end{array}$ & $\begin{array}{c}\text { EE } \\
(\%)\end{array}$ & $\begin{array}{c}\text { CF } \\
(\%)\end{array}$ & $\begin{array}{c}\text { NFE } \\
(\%)\end{array}$ & $\begin{array}{c}\text { TDN } \\
(\%)\end{array}$ \\
\hline Elephant & 19.29 & 85.02 & 14.98 & 11.05 & 5.55 & 28.51 & 39.91 & 53.45 \\
King & 22.99 & 88.82 & 11.18 & 12.43 & 4.26 & 23.57 & 48.56 & 55.40 \\
Dwarf elephant & 13.68 & 81.89 & 18.11 & 10.50 & 3.72 & 25.6 & 42.07 & 53.45 \\
Guinea & 18.14 & 87.48 & 12.52 & 11.73 & 2.11 & 29.44 & 39.63 & 49.47 \\
Setaria & 13.22 & 82.91 & 17.09 & 11.09 & 6.15 & 28.03 & 42.21 & 54.20 \\
\hline
\end{tabular}

Note : DM: dry matter, OM: organic matter, CP: crude protein, EE: extract ether, CF: crude fiber, NFE: nitrogen free extract, TDN: total digestible nutrient; NFE formula $=100-(\% \mathrm{CP}+\% \mathrm{EE}+\% \mathrm{CF}+\% \mathrm{NFE})$, TDN formula $=(70,60+$ $0,259 \mathrm{CP}+1,01 \mathrm{EE})-(0,76 \mathrm{CF}+0,0991 \mathrm{NFE})$ (Hartadi et al., 1990). 
and harvest period. The main characteristic of grass is its crude fiber, so the main purpose of giving forage to dairy cattle is as a source of fiber. Utomo (2012) stated that fiber sourced feed ingredients contained a minimum of $18 \%$ CF. Similarly, the present study reported a crude fiber of $23.57-29.44 \%$ of five types of forages. Weiss et al. (2008) further stated that forage has low levels of protein and fat. Protein levels are always below $20 \%$ and fat is always lower than $10 \%$. Energy supply in plants is generally in the form of cellulose so minimal fat and protein are accommodated in plant parts.

Paulson et al. (2008) stated that the nutritional value of forage influenced milk production. The effects vary greatly, depending on the combination and the feed technology applied. Forage has a fairly good digestible value compared to legumes or agricultural waste. Some legumes and agricultural wastes have antinutrient substances which can reduce their performance in the ration.Table 1 shows that the OM content in each type of forage is quite high, which is above $80 \%$. Syamsi et al. (2019) explained that information on potential forage can be developed based on organic matter and protein. Both levels and degradability values can provide information on the potential supply of ammonia and energy. The degradation of OM and protein for the five grass types were assessed and presented on Table 2.

The regression analysis of the degradation of g protein and $\mathrm{Kg}$ OM in the span of $2^{\text {nd }}, 4^{\text {th }}, 6^{\text {th }}$, $8^{\text {th }}, 12^{\text {th }}, 24^{\text {th }}, 48^{\text {th }}$, and $72^{\text {th }}$ in each type of forage indicated a different equation. Silva et al. (2013) explained that the degradation of organic matter and protein until the peak collection would form an upward linear curve. However, the increase in the curve for each feed ingredient was different due to differences in nutritional content and degradation kinetic of organic matter and protein of each feed ingredient. It was because the levels and digestibility of $\mathrm{OM}$ and protein in each forage are different. It was confirmed by previous studies by Syamsi et al. (2017) and Syamsi et al. (2019) in that each feed ingredient had different nutritional and digestive value characteristics. Furthermore, Table 2 shows that the coefficient of determination of each equation is above $90 \%$. This result was higher than Syamsi et al. (2019) on various types of forage materials. Additionally, Syamsi et al. (2017) confirmed that the degradation graph of feed ingredients has fluctuated from time to time, where the highest increase in degradation occurred at 20-30 hours, longer than that of the concentrate group (4 hours).

The PES index calculation results (Table 3 ) show that elephant grass has a high index (0.72), while the king, dwarf elephant, guinea and setaria grass have their respective medium indices by $0.66,0.69,0.58$, and 0.68 , respectively, grouped based on Sinclair et al. (1995). It was attributed to the almost similar degradation of protein and organic matter in the forage. An almost balanced degradation

Table 2. The equation of the linear regression results in the degradation of protein and organic matter (OM) of various types of forages for 72 hours

\begin{tabular}{|c|c|c|c|c|}
\hline \multirow{2}{*}{ Type of Forages } & \multicolumn{2}{|c|}{ g protein degradation } & \multicolumn{2}{|c|}{ Kg OM degradation } \\
\hline & The equation & $\mathrm{R}^{2}$ & The equation & $\mathrm{R}^{2}$ \\
\hline Elephant & $y=2.3336 x+99.867$ & 0.9369 & $y=0.0208 x+0.213$ & 0.9369 \\
\hline King & $y=2.3553 x+179.78$ & 0.9183 & $y=0.0221 x+0.2975$ & 0.9183 \\
\hline Dwarf elephant & $y=2.0951 x+119.61$ & 0.9344 & $y=0.0205 x+0.1351$ & 0.9344 \\
\hline Guinea & $y=1.466 x+132.99$ & 0.9186 & $y=0.0129 x+0.1548$ & 0.9186 \\
\hline Setaria & $y=1.8625 x+154.27$ & 0.9297 & $y=0.019 x+0.2893$ & 0.9297 \\
\hline
\end{tabular}

Note : g: gram; Kg: kilogram; OM: organic matter; y: degradation rate; $\mathrm{R}^{2}$ : coefficient of determination; degradation observation was carried out for 72 hours with the observation time at 2nd, 4th, 6th, 8th, 12th, 24th, 48th, and 72nd hours; degradation is calculated by estimating digestibility in $5 \mathrm{~kg}$ of feed ingredients. 
Table 3. The degradation rate of protein and organic matter (OM) and protein-energy synchronization index of various types of forage

\begin{tabular}{lccc}
\hline \multirow{2}{*}{ Type of Forages } & \multicolumn{2}{c}{ Degradation rate } & \multirow{2}{*}{ PES index } \\
\cline { 2 - 3 } & g protein/hour & Kg OM/hour & 0.72 \\
Elephant & 267.8862 & 1.7106 & 0.66 \\
King & 349.3616 & 1.8887 & 0.69 \\
Dwarf elephant & 270.4572 & 1.6111 & 0.58 \\
Guinea & 238.542 & 1.0836 & 0.68 \\
Setaria & 288.37 & 1.6573 & \\
\hline Note: g: gram; Kg: kilogram; OM: organic matter; y: degradation rate; PES: protein-energy syincronization; degradation & \\
\multicolumn{2}{l}{ observation was carried out for 72 hours with the observation time at 2nd, 4th, 6th, 8th, 12th, 24th, 48th, and 72nd } \\
\multicolumn{2}{l}{ hours; degradation is calculated by estimating digestibility in 5 kg of feed ingredients; the PES index is calculated } \\
based on the equation of Hermon et al. (2008).
\end{tabular}

results in an almost simultaneous availability of ammonia and energy resulted in a high index. According to Waldi et al. (2017), fiber-source feed had a high index tendency, which allowed a high use of forages in the ration to increase the PES index figure to close to 1 . Waldi et al. (2017) and Syamsi et al. (2017) reported that the use of grass increased with the PES index in the ration. In addition, dthe forage synchronization index was higher than the concentrate group, so the use of forages was a counterweight to the concentrate in the ration.

The study of the PES index is very important related to the preparation of dairy rations. There have been many research studies that proved the positive impacts of regulating rations with PES index. Syamsi et al. (2017) claimed that the preparation of rations with a PES index approaching 1 linearly increased microbial protein synthesis (MPS), while Syamsi et al. (2018) proved the existence of energy efficiency based on the production of volatile fatty acids in the ration based on the PES index. Yang et al. (2010) confirmed that proteinenergy synchronization potentially increased livestock productivity. Therefore, PES index investment in various types of feed ingredients is necessary. The results of PES index calculation on five types of forages can be used as the starting point in the development of dairy cattle feeds based on PES index in Indonesia.

\section{Conclusions}

The study concluded that elephant grass has a high level of PES index, while king, dwarf elephant, guinea, and setaria grass have a medium level for compiling dairy rations.

\section{Acknowledgement}

The autors are grateful to LPPM Unsoed for the opportunity to obtain research funding through Riset Dosen Pemula (RDP) Scheme.

\section{References}

AOAC. 2005. Official Methods of Analysis. $15^{\text {th }} \mathrm{Ed}$. Assosiation of Official Analytical Chemist, Washington DC. Vol 4 pp 1-68.

Ginting, S. P. 2005. Sinkronisasi Degradasi Protein dan Energi dalam Rumen untuk Memaksimalkan Produksi Protein Mikroba. Wartazoa. 15 (1): 110. (in Indonesian with abstract in English)

Hartadi, H., S. Roksohadipradja and A.D. Tillman. 1990. Tabel Komposisi Pakan untuk Indonesia. UGM Press. Yogyakarta. pp 11-12.

Hermon, M., Suryahadi, K. G. Wiryawan and S. Hardjosoewignjo. 2008. Nisbah Sinkronisasi Suplai N-Protein dan Energi dalam Rumen Sebagai Basis Formulasi Ransum Ternak Ruminansia. Media Peternakan. 31 (3): 186-194. (in Indonesian with abstract in English)

Orskov, E. R. and I. McDonald. 1979. The Estimating of Protein Degradability in The Rumen From Incubation Measurement Weighted Activating to Rate of Passage. Journal of Agrculture Science. Camb. 92: 499-503. 
Silva, S. P. da., M. T. Rodrigues, R. A. M. Vieira and M. M. C. da Silva. 2013. In Vitro Degradation Kinetics of Protein and Carbohyidrate Fraction of Selected Tropical Forage. Bioscience Journal. 29 (5): 1300-1310.

Syamsi, A. N., F. M. Suhartati and W. Suryapratama. 2017. Pengaruh Daun Turi (Sesbania grandiflora) dan Lamtoro (Leucaena leucocephala) dalam Ransum Sapi Berbasis Indeks Sinkronisasi Protein - Energi Terhadap Sintesis Protein Mikroba Rumen. Pastura. 6 (2): 47-52. (in Indonesian with abstract in English)

Syamsi, A. N., T. Y. Astuti and P. Soediarto. 2018. Volatile Fatty Acids and Methane Profile of Dairy Cattle Ruminal Fluid was Gived Legumes in Ration Based on Synchronization Protein-Energy Index. Buletin Peternakan. 42 (4): 283-289.

Syamsi, A. N., L. Waldi, H. S. Widodo, and Harwanto. 2019. Branched Chain Volatile Fatty Acids Profile of Rumen Fluids Suplemented by Different Meal Protein Sources and Protein-Energy Synchronization Index. In: Proceeding of the 1st Animal Science and Food Technology Conference (AnSTC). Purwokerto, August 2019. Pp: 012060 (1-6).

Syamsi, A. N., H. S. Widodo, Harwanto, M. F. Ifani and R. A. Rahayu. 2019. Potensi Nilai Nutrisi Dan Indeks Sinkronisasi Protein-Energi Berbagai Jenis Jerami Segar Untuk Ternak Perah. Prosiding Seminar Nasional Pengembangan Sumber Daya Perdesaan dan Kearifan Lokal Berkelanjutan IX. Purwokerto, November 2019. (in Indonesian with abstract in English)

Paulson, J., M. R. Knight, J. Linn and H. Jung. 2008. Dairy Forages Focus. USDA-ARS. Minnesota: Pp: 323-325.
Purbajanti, E. D., D. Soetrisno, E. Hanudin and S.P.S. Budi. 2007. Karakteristik Lima Jenis Rumput Pakan pada Berbagai Tingkat Salinitas. Journal Indonesian Tropical Animal and Agriculture. 32 (3): 186-193. (in Indonesian with abstract in English)

Sinclair, L.A., P.C. Garnsworthy, J.R. Newbold and P.J. Buttery. 1995. Effects of Synchronizing the Rate of Dietary Energy and $\mathrm{N}$ Release in Diets with a Similar Carbohydrate Composition on Rumen Fermentation and Microbial Rumen Protein Synthesis in Sheep. Journal of Agriculture Science. Camb. 124:463-472.

Tilley, J. M. A. and R. A. Terry, 1963. The Relationship Between the Soluble Constitutent Herbage and Their Dry Matter Digestibility. Journal of the British Grassland Society. 18: 104-111.

Utomo, R. 2012. Evaluasi Pakan dengan Metode Noninvansif. Citra Ajiprama. Yogyakarta.

Waldi, L., W. Suryapratama and F.M. Suhartati. 2017. Pengaruh Penggunaan Bungkil Kedelai dan Bungkil Kelapa dalam Ransum Berbasis Indeks Sinkronisasi Energi dan Protein Terhadap Sintesis Protein Mikroba Rumen Sapi Perah. Journal of Livestock Science and Production. 1 (1): 1-11. (in Indonesian with abstract in English)

Weiss, W. P., M.L. Eastridge and J.F. Underwood. 2008. Forages for Dairy Cattle. Ohio State University Fact Sheet. Ohio. Pp: 1-9.

Yang, J. Y., J. Seo, H. J. Kim, S. Seo and J. K. Ha. 2010. Nutrients Synchrony: Is it a Suitable Strategy to Improve Nitrogen Utilization and Animal Performance. Asian Australian Journal Animal Science. 23(7): 972-979. 